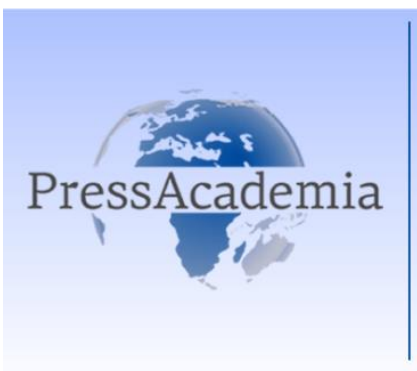

Press Academia Procedía

\title{
USING MULTI-CRITERIA DECISION MAKING FOR SELECTION PROVINCES FOR FATTENING FARM
}

\author{
DOI: 10.17261/Pressacademia.2017.581 \\ PAP-WCTIE-V.5-2017(19)-p.130-138
}

\author{
Burcu Ozcan ${ }^{1}$, Gulsen Akman ${ }^{2}$, Cagin Karabicak ${ }^{3}$, Yasin Erdogan ${ }^{4}$ \\ Kocaeli University, Engineering Faculty, Industrial Engineering Department , burcu.ozcan@kocaeli.edu.tr \\ Kocaeli University, Engineering Faculty, Industrial Engineering Department, akmang@kocaeli.edu.tr \\ Kocaeli University, Engineering Faculty, Industrial Engineering Department, cagink@kocaeli.edu.tr \\ Kocaeli University, Engineering Faculty, Industrial Engineering Department, yasinerdogan0103@gmail.com
}

\begin{abstract}
Turkey has a high potential in the field of agriculture and livestock production. Turkey has a long history in the production of livestock system, which became the "buffer" sector of economy and the "locomotive" sector of Turkey. Although nowadays pastures are decreased, Turkey has quite large pastures. Besides, the domestic demand for meat in Turkey is quite large and tend to a show considerable growth. Animal husbandry is carrying great importance in terms of protein source and fattening cattle in the red meat production. In this sense, the development of meat production in terms of quality and quantity is also very necessary in terms of the nutritional problem that arises parallel to the growing population. In this study, the causes of increase in meat prices in Turkey were investigated, and the findings showed that, the cause of the price increases made as inadequate animal fattening. As a result, it was decided to establish a new place for the production of cattle-raising. Before starting the construction of the fattening livestock farm, firstly the location of the establishment is considered. In the decision-making process, it is quite difficult to make choices because of the different alternatives in terms of various criteria's. For this purpose, the PROMETHEE (Preference Ranking Organization Method for Enrichment Evaluation) method, which is an easy and straightforward method of multi-criteria decision making techniques which are frequently used in researches in recent years, has been used to select the place of establishment in Turkey. The choice of fattening farm establishment site was evaluated in 81 provinces; cattle feed areas, demand on meat, urban development index value, average minimum temperature, average maximum temperature, precipitation amount and grant support criteria were evaluated with using the PROMETHEE method. The interactions between the criterion and the criteria that influence the process were determined as a result of the survey conducted. As a result of this survey study, criteria weights and criterion values were determined by Analytical Hierarchy Process (AHP) method and solved by PROMETHEE method considering the results. As a conclusion, the most suitable and the less suitable provinces for fattening livestock farm are selected
\end{abstract}

Keywords: Multiple criteria decision making methods, analytical hierarchy process (AHP) method, PROMETHEE, selection of establishment place for fattening farms in Turkey.

\section{INTRODUCTION}

In the rapidly developing and changing world, while adequate and balanced nutrition is at the beginning of the problems, it actually contains solutions in itself. Livestock as a branch of agriculture has a strategic importance in terms of revitalizing development in the country's economy. Livestock nowadays has become an industry in developed countries and it become an integral part of the economy. This situation suggests that agriculture and therefore animal husbandry is a sector that needs to be developed at national level.

According to the TUIK (Turkish Statistics Institution) data, the GDP growth rate with fixed prices for the last 11 years increased by $4.9 \%$ on average, while the growth rate in the agricultural sector was $2.2 \%$. This difference in rates of change has reduced the share of agriculture in GDP from $12.2 \%$ to $9.2 \%$.

In their study, Ocaklı et al. report that in the future, the demand for animal-origin food will not increase significantly but that the demand for meat and dairy products will increase by two times in countries with rapid population growth in the 2020s. In Turkey, the livestock sector has tried to develop according to years but these developments have not been able to 
catch up with the growing population and the growing livestock sector in intercountries. The fact that agriculture and animal husbandry are not being carried out in our country in large quantities has dragged us into importing, and causing the animals to be taken from foreign countries.

Turkey thought that red meat prices are very high in 2010. Therefore, Turkey started to import beef, butchery and live cattle and sheep lamb. However, the carcass and meat prices continued to increase in the mentioned period.

Though the exact number is not known, it is estimated that over 30.000 fattening businesses are in our country and more than $90 \%$ of these businesses can be considered as small enterprises.

Planning and projecting of animal shelters in our country in order to provide suitable environmental conditions and improvement of existing shelters are obligatory (Ekmekyapar, 1991). In our country where climatic conditions show differences between regions, the preparation of shelter plans suitable for the special conditions of the regions depends on making the right facility place.

Beef farming are made to increase the yield of beef. In order to obtain more meat and better quality meat from younger males and females who do not have breeding features, milk cattle breeders who are left out of the squad, and old cattle, a special nutrition is applied for a certain period of time before slaughter, and this period is called beef farming (Hacıbebekoğlu et al., 2013). Basic methods of fattening are classified as pasture fattening (entansive), before pasture fattening than barn fattening (semi-entansive), and barn fattening (entansive).

Ecological animal husbandry is a production system which number of animal is low, has appropriate feeding and shelter conditions, produce quality product with an appropriate production and marketing methods. In order to design an ecological animal husbandry, firstly selection of facility place should be performed appropriately and correctly. The climate, the location and the environmental factors are very important for the place selection.

People make decisions in many topics during their lives. These decisions have certain criteria. The weights of these criteria vary from person to person. In the selection of the place of beef farming, weights of criteria, the selling, pastures, temperature or IPARD (Rural Development Component) support vary from person to person. A similar situation applies to businesses. For this reason, Multi Criteria Decision Making (MCDM) techniques are used to make scientific selection in evaluating alternatives when people or businesses make decisions.

In this study, it was aimed to determine the most suitable place of beef farming in cities in Turkey by using multi criteria decision making techniques. Firstly, a literature research was carried out. In the first phase of the study, the criteria affecting the place of beef farming were determined. The weights of these criteria were determined by AHP method and the accuracy was checked by consistency analysis. According to these criteria, 81 provinces were evaluated with the help of Visual Promethee package program which is application software of PROMETHEE method. In the last part, the results of the work were evaluated and various suggestions were made.

\section{LITERATURE REVIEW}

\subsection{Studies Related with Animal Husbandry and Beef Farm}

With parallel to the importance of the livestock sector in our country, there are a number of studies published in this issue.

Vural and Fidan (2007) reported that the activities types of animal husbandry in Turkey village-type; animal husbandry, agricultural worker activity which feeds one or two cattle's for family consumption, businesses which performs animal husbandry as a subsidiary activity beside herbal production, specialized businesses to produce to market and modern animal.

Çakır and Saner (2005) compared the traditional and ecological animal husbandry systems in Turkey, which have a great potential in terms of animal existence They evaluated necessity and applicability of ecological system in Turkey. Also they evaluated current situation according to different animal production branches.

Kıral (1993) made a general assessment of the technical and economic aspects of beef cattle breeding in Turkey by focusing on the importance and the role of fattening businesses in Turkish livestock farming. In the study, economic analysis of fattening enterprises which have 1-50 heads cattle's, 51-100 heads 1-50 heads cattle's and over 100 heads 1-50 heads cattle's were carried out by emphasizing the socio-economic structure of fattening enterprises (Şerefoğlu, C., 2008).

Ömürbek et al. (2013) have tried to determine the areas where livestock can be done in the province of Isparta by using the AHP method in. In the study, 7 districts in Isparta province were compared according to 5 different criteria (location, environmental factors, labor force, investment costs, laws) and decided to optimum area. 


\subsection{Multi Criteria Decision Making Methods}

Multi-criteria decision-making methods achieve the best compromised solution by evaluating available alternatives based on deterministic criterion values. Genç and Masca (2013) have included in their articles the statements that the decision maker can sort, group or choose among the available alternatives by means of the MCDM methods. When the literature is examined, it is seen that mathematical programming and multi-criteria decision making methods are generally used as numerical methods in the studies about the place of beef farming.

\subsubsection{Analytical Hierarchy (AHP) Method}

Saaty (1990) describes the Analytical Hierarchy Process (AHP) method, which is widely used in computer aided multi-criteria decision making defined as a method which is based on pair wise comparison of alternatives according to common criterion and provides important support to the decision maker in reaching the conclusion of multi-criteria and multichoice.

Cengiz and Çelen (2003) used AHP method in rural development, and at the end of the study, they found that AHP is a useful method in rural development studies. Eren (2006) worked on the determination of the best location in the leather industry using the AHP method. Özdağoğlu (2008) used the fuzzy analytical production process to study the facility place, and as a result he determined the appropriate one from the 4 alternative place (Ülke, 2016).

Özel et al. (2014) used the AHP method to select the appropriate area for the new forestation work to be carried out in the Bartın Havza. Bakan (2013) used the AHP method to determine the appropriate districts among 14 district alternatives to establish the university according to the criteria determined.

\subsubsection{PROMETHEE}

The PROMETHEE method is a multi-criteria prioritization method developed by Jean-Pierre Brans in 1982. The PROMETHEE method has been developed because of the difficulties in implementation of existing prioritization methods in the literature, and used in many studies (Dağdeviren and Eraslan, 2008). Some of the PROMETHEE applications in the literature are summarized below.

Maragou and Tsakiri (2005) proposed that PROMETHEE can be used to simplify the selection process alternative practices of reducing the damage caused by flood problems. Dağdeviren and Eraslan (2008) used PROMETHEE in supplier selection problem of a firm and calculate priority of alternative suppliers.

Athawale and Chakraborty (2010) have solved the problem of more efficient plant place selection using the PROMETHEE II method, and found out how much this selection has an effect in production organizations.

Kutay and Tektüfekçi (2013) used the PROMETHEE-GAIA approach which is one of computer-aided multi-criteria decisionmaking processes in order to determine the managerial accounting decisions according to the degree of importance. Soba (2012) applied PROMETHEE method, using criteria- prices, fuel, maximum speed, safety, horsepower and performance - for six different panelvans in the same class.

Genç and Masca (2013) used TOPSIS and PROMETHEE methods to obtain ranking of European Union countries and Turkey according to some economic criteria and compared their results. As a result, it is seen that the ranking values obtained as a result of the PROMETHEE and TOPSIS methods are very similar to each other

\section{DATA AND METHODOLOGY}

Many different methods can be used together to choose the place of beef farming. AHP, ANP, Data Envelopment Method, ELECTRE, TOPSIS, PROMETHEE and integration of these methods are generally used. Selection criteria and method selection are the most important features of facility place selection. When the place of beef farming is selected, AHP and PROMETHEE methods which be able to show the difference in the comparison stage and including mathematical solution will be used. By using these methods, a different point of view has been tried to be achieved.

\subsection{Analytic Hierarchy Process (AHP)}

The AHP method is based on the naturalness of the human brain in view of events (Kokangül and Susuz, 2009). AHP method is based on pair wise comparison of alternatives according to the criteria. The AHP provides decision support in solving multi-criteria and multi-alternative problems (Çiftçioğlu, 2013). The AHP was firstly introduced by Myers and Alpert in 1968. The AHP method developed by Saaty in 1977 consists of five basic steps (Ömürbek et al., 2014). In the first step, the problem is defined, the main objective is determined in the hierarchical structure. In the second step, hierarchy of criteria and alternatives is created. In the third step; pair wise comparison matrices are created. In the fourth step, weight vector is 
found. In the last step, the consistency rate is calculated. In case of inconsistency, pair wise comparisons are controlled, and process is repeated until they are consistent.

\subsection{PROMETHEE}

The PROMETHEE method, which was introduced in 1982, is a multi-criteria sorting method. PROMETHEE is a method that allows for the sorting of alternatives taking into account conflicting criteria. This method starts with the evaluation table. Alternatives in this table are evaluated according to different criteria. There are two kinds of information needed for the implementation of PROMETHEE. These are function preferences of the decision maker and the relative importance of the considered criteria for comparing the contribution of alternatives in each criterion. The PROMETHEE method consists of 7 steps (Dağdeviren and Erarslan, 2008); In the first step; The data matrix $A=(a, b, c, \ldots)$ is constructed for the alternatives evaluated by the weight of $w=(w 1, w 2, \ldots, w k)$ and the criterion $c=(f 1, f 2, \ldots, f k)$. In the second step, the preference function is defined for each criterion. In the third step, the common preference functions for alternative pairs are determined on the basis of preference functions. In the fourth step, the preference index for the alternative is calculated based on the common preference functions. In the fifth step; Positive $(\Phi+)$ and negative ( $\Phi-)$ superiorities are determined for each alternative. In the sixth step; Partial priorities are determined by PROMETHEE I. Partial priorities explain the relationships of alternatives to each other. These relations are stated the preference situations of the alternatives and the determination of alternatives that are indifferent from each other. In the seventh step, full priorities for alternatives are calculated using PROMETHEE II and the calculated values are evaluated in the same plane as all alternatives and the exact order is determined.

\subsection{Methodology}

In this study, the selection of the facility place of beef farming among the provinces in Turkey was realized by using AHP and PROMETHEE methods. Criteria weights were determined by the AHP method and the ordering of the provinces was performed by PROMETHEE method.

As a result of the study, AHP and PROMETHEE methods were used to determine the ideal provinces and various suggestions were developed. Microsoft Excel and Visual Promethee package programs are used for calculations of AHP and PROMETHEE methods.

In the first phase of the study, the basic criteria required for the establishment of the beef farming were determined with interviews with the staff of the Directorate of Agriculture and in order to obtain expert opinions before the implementation. These criteria are, percentage of feed crop area, percentage of beef demand, urban development index, average minimum temperature, average maximum temperature, annual precipitation amount, grant supports. The criteria are shown in Table 1 below.

Table 1: Affecting criteria of selection of facility place

\begin{tabular}{|l|l|}
\hline & \multicolumn{1}{|c|}{ Criteria } \\
\hline H1 & Percentage of feed crop area \\
\hline H2 & Percentage of beef demand \\
\hline H3 & Urban development index \\
\hline H4 & Average minimum temperature \\
\hline H5 & Average maximum temperature \\
\hline H6 & Annual precipitation amount \\
\hline H7 & IPARD grant supports \\
\hline
\end{tabular}

In the second stage of study, As a result of the interviews among the employees, the relations between the criteria were determined, and the analytical averages of the values were determined, and the percentages were calculated, and the AHP weight matrix was formed. Weight percentages of the criteria were found as a result of AHP analysis. The accuracy of the weighted matrix was checked by consistency analysis. The results are shown in Table 2.

Table 2: AHP Weighted Matrix

\begin{tabular}{|l|l|l|l|l|l|l|l|l|}
\hline & H1 & H2 & H3 & H4 & H5 & H6 & H7 & W \\
\hline H1 & 0,26 & 0,24 & 0,26 & 0,29 & 0,29 & 0,29 & 0,23 & 0.26 \\
\hline H2 & 0,49 & 0,46 & 0,35 & 0,41 & 0,41 & 0,41 & 0,45 & 0.42 \\
\hline H3 & 0,04 & 0,06 & 0,04 & 0,02 & 0,02 & 0,02 & 0,05 & 0.03 \\
\hline H4 & 0,05 & 0,07 & 0,09 & 0,06 & 0,06 & 0,06 & 0,05 & 0.06 \\
\hline H5 & 0,05 & 0,07 & 0,09 & 0,06 & 0,06 & 0,06 & 0,05 & 0.06 \\
\hline
\end{tabular}




\begin{tabular}{|l|l|l|l|l|l|l|l|l|}
\hline H6 & 0,05 & 0,07 & 0,09 & 0,06 & 0,06 & 0,06 & 0,05 & 0.06 \\
\hline H7 & 0,09 & 0,09 & 0,17 & 0,12 & 0,12 & 0,12 & 0,1 & 0.11 \\
\hline \multicolumn{10}{|l|}{ When ratio is $0,01295<0,10$ result is consistent } \\
\hline
\end{tabular}

In the third stage of the study, the appropriate preference function was chosen to implement the PROMETHEE method, and these values are shown in Table 3. After the preference function is determined, Visual Promethee program is used to implement the method. ("1" is not included in IPARD grant grants, "0" is set.) (1 - number of cattle / population) * 100.

Table 3: PROMETHEE Preference Functions and Data

\begin{tabular}{|c|c|c|c|c|c|c|c|}
\hline CRITERIA & H1 & $\mathrm{H} 2$ & H3 & $\mathrm{H} 4$ & H5 & $\mathrm{H} 6$ & $\mathrm{H7}$ \\
\hline Units & $\%$ & $\%$ & Index & $-{ }^{\circ} \mathrm{C}$ & $+{ }^{\circ} \mathrm{C}$ & $\mathrm{mm}$ & IPARD \\
\hline \multicolumn{8}{|c|}{ Preferences } \\
\hline Min/Max & Max & Max & Max & Max & Min & Max & Max \\
\hline Weights (W)) & 0.26 & 0.42 & 0.03 & 0.06 & 0.06 & 0.06 & 0.11 \\
\hline Preference Functions & $\begin{array}{l}\text { Type I } \\
\text { (Usual) }\end{array}$ & $\begin{array}{l}\text { Type I } \\
\text { (Usual) }\end{array}$ & $\begin{array}{l}\text { Type I } \\
\text { (Usual) }\end{array}$ & $\begin{array}{l}\text { Type II } \\
\text { (U-Shape) }\end{array}$ & \begin{tabular}{|l|} 
Type I \\
(Usual)
\end{tabular} & $\begin{array}{l}\text { Type I } \\
\text { (Usual) }\end{array}$ & $\begin{array}{l}\text { Type III } \\
\text { (V-Shape) }\end{array}$ \\
\hline $\mathbf{Q}$ & $\mathrm{n} / \mathrm{a}$ & $\mathrm{n} / \mathrm{a}$ & $\mathrm{n} / \mathrm{a}$ & $-10,00$ & \begin{tabular}{|l|}
$+30,00$ \\
\end{tabular} & $\mathrm{n} / \mathrm{a}$ & $\mathrm{n} / \mathrm{a}$ \\
\hline $\mathbf{P}$ & $\mathrm{n} / \mathrm{a}$ & $\mathrm{n} / \mathrm{a}$ & $\mathrm{n} / \mathrm{a}$ & $\mathrm{n} / \mathrm{a}$ & $\mathrm{n} / \mathrm{a}$ & $\mathrm{n} / \mathrm{a}$ & 1,00 \\
\hline \multicolumn{8}{|l|}{ Provinces } \\
\hline ADANA & 2,36 & 90,21 & 0,47 & 5,5 & 34,6 & 654,4 & 0 \\
\hline ADIYAMAN & 0,63 & 85,50 & 0,38 & 1,3 & 37,7 & 695,1 & 0 \\
\hline AFYONKARAHISAR & 18,85 & 55,54 & 0,63 & $-3,4$ & 29,5 & 427,3 & 1 \\
\hline AĞRI & 32,70 & 37,77 & 0,30 & $-15,9$ & 30 & 519,6 & 1 \\
\hline AMASYA & 16,06 & 46,60 & 0,59 & $-0,9$ & 31,3 & 459,4 & 1 \\
\hline ANKARA & 28,43 & 93,10 & 0,62 & -3 & 30,3 & 366,2 & 1 \\
\hline ANTALYA & 16,05 & 93,16 & 0,55 & 6 & 34,2 & 1074,6 & 0 \\
\hline ARTVIN & 53,15 & 65,88 & 0,63 & $-0,2$ & 26,2 & 701,8 & 0 \\
\hline AYDIN & 2,57 & 67,40 & 0,54 & 4,3 & 36,1 & 644 & 1 \\
\hline BALIKESIR & 6,63 & 58,76 & 0,63 & 1,3 & 31,3 & 576,8 & 1 \\
\hline BILECIK & 19,06 & 83,37 & 0,63 & $-0,3$ & 28,6 & 454,5 & 0 \\
\hline BINGÖL & 27,10 & 54,17 & 0,44 & $-6,1$ & 34,5 & 944,1 & 0 \\
\hline BiTLIS & 10,23 & 83,13 & 0,40 & $-6,4$ & 30,7 & 1221,2 & 0 \\
\hline BOLU & 17,87 & 52,75 & 0,66 & $-3,2$ & 28 & 553,9 & 0 \\
\hline BURDUR & 7,86 & 21,62 & 0,55 & $-0,8$ & 32,2 & 426,9 & 1 \\
\hline BURSA & 15,58 & 93,44 & 0,60 & 1,7 & 31 & 695,1 & 1 \\
\hline ÇANAKKALE & 9,70 & 60,70 & 0,59 & 3,2 & 30,7 & 628,8 & 1 \\
\hline ÇANKIRI & 35,96 & 30,00 & 0,60 & -4 & 31,1 & 410,6 & 1 \\
\hline ÇORUM & 34,85 & 59,11 & 0,50 & $-4,2$ & 29,4 & 431,5 & 1 \\
\hline DENIZLi & 5,92 & 75,41 & 0,59 & 2,3 & 34,4 & 566,1 & 1 \\
\hline DIYARBAKIR & 2,94 & 79,02 & 0,35 & $-2,3$ & 38,5 & 490,1 & 1 \\
\hline EDIRNE & 0,22 & 62,15 & 0,57 & $-0,6$ & 31,7 & 602,4 & 0 \\
\hline ELAZIĞ & 19,52 & 73,41 & 0,48 & -4 & 34,2 & 410,2 & 1 \\
\hline ERZINCAN & 23,13 & 59,56 & 0,57 & -7 & 31,9 & 376,8 & 1 \\
\hline ERZURUM & 30,47 & 14,38 & 0,53 & $-14,3$ & 27,3 & 406 & 1 \\
\hline ESKIŞEHIR & 37,57 & 83,65 & 0,62 & $-3,5$ & 29,3 & 370 & 0 \\
\hline GAZIANTEP & 1,77 & 92,05 & 0,47 & $-0,8$ & 35,3 & 552,7 & 0 \\
\hline GIRESUN & 37,96 & 80,20 & 0,58 & 4,4 & 26,5 & 1266 & 1 \\
\hline GÜMÜŞHANE & 32,24 & 52,17 & 0,53 & $-5,7$ & 28,7 & 461,3 & 0 \\
\hline HAKKARI & 5,40 & 86,50 & 0,33 & $-8,1$ & 30,9 & 781,3 & 0 \\
\hline HATAY & 0,77 & 92,30 & 0,44 & 4,7 & 32 & 1128,9 & 1 \\
\hline ISPARTA & 16,12 & 65,50 & 0,67 & $-1,8$ & 30,5 & 545,4 & 1 \\
\hline MERSIN & 11,22 & 94,16 & 0,48 & 6,3 & 31,5 & 588,4 & 1 \\
\hline ISTANBUL & 0,25 & 99,49 & 0,65 & 3,1 & 26,8 & 813,2 & 0 \\
\hline izMiR & 2,41 & 85,74 & 0,60 & 5,9 & 33,2 & 690,3 & 0 \\
\hline KARS & 0,92 & $-71,02$ & 0,38 & -16 & 26,2 & 499,3 & 1 \\
\hline KASTAMONU & 20,62 & 40,77 & 0,57 & $-4,3$ & 28 & 485,2 & 1 \\
\hline
\end{tabular}




\begin{tabular}{|c|c|c|c|c|c|c|c|}
\hline KAYSERI & 37,21 & 78,23 & 0,55 & $-6,8$ & 30,8 & 388,6 & 0 \\
\hline KIRKLARELI & 0,83 & 58,82 & 0,58 & 0 & 30,5 & 570,2 & 0 \\
\hline KIRŞEHIR & 40,54 & 31,74 & 0,59 & $-4,1$ & 29,7 & 379,9 & 0 \\
\hline KOCAELI & 15,50 & 93,72 & 0,59 & 3,3 & 29,6 & 809,3 & 0 \\
\hline KONYA & 30,09 & 64,10 & 0,62 & $-3,9$ & 30,2 & 318,7 & 1 \\
\hline KÜTAHYA & 14,19 & 68,37 & 0,65 & $-3,2$ & 28,5 & 560,3 & 1 \\
\hline MALATYA & 44,26 & 76,35 & 0,52 & -3 & 34 & 382,6 & 1 \\
\hline MANISA & 4,50 & 83,97 & 0,58 & 3,1 & 34,9 & 730,1 & 1 \\
\hline KAHRAMANMARAŞ & 12,52 & 84,38 & 0,53 & 1,3 & 35,9 & 732,1 & 1 \\
\hline MARDIN & 2,38 & 89,16 & 0,29 & 0,5 & 34,9 & 666,4 & 1 \\
\hline MUĞLA & 17,33 & 77,34 & 0,54 & 1,6 & 33,6 & 1169,4 & 0 \\
\hline MUŞ & 15,88 & 23,20 & 0,28 & $-11,1$ & 33 & 762,7 & 1 \\
\hline NEVŞEHIR & 24,41 & 73,47 & 0,56 & $-3,8$ & 28,4 & 415,2 & 1 \\
\hline NiĞDE & 32,65 & 58,95 & 0,53 & $-4,5$ & 29,4 & 336,4 & 0 \\
\hline ORDU & 38,88 & 83,05 & 0,51 & 3,8 & 27,3 & 1035,1 & 1 \\
\hline RiZE & 0,00 & 93,18 & 0,63 & 3,5 & 26,6 & 2245,3 & 0 \\
\hline SAKARYA & 0,16 & 83,58 & 0,67 & 2,9 & 29,4 & 834,6 & 0 \\
\hline SAMSUN & 8,14 & 76,93 & 0,57 & 3,9 & 27 & 706,3 & 1 \\
\hline SiIRT & 15,13 & 93,70 & 0,42 & $-0,6$ & 37,1 & 716,3 & 0 \\
\hline SINOP & 39,49 & 52,79 & 0,63 & 4,2 & 26,2 & 676 & 0 \\
\hline SivAS & 38,46 & 55,73 & 0,56 & -7 & 28,5 & 432,3 & 1 \\
\hline TEKIRDAĞ & 0,02 & 85,29 & 0,58 & 2,1 & 28,1 & 589,1 & 0 \\
\hline TOKAT & 13,10 & 59,30 & 0,56 & $-1,7$ & 29,6 & 432,4 & 1 \\
\hline TRABZON & 0,00 & 83,62 & 0,60 & 4,4 & 26,8 & 810,2 & 1 \\
\hline TUNCELI & 51,16 & 64,35 & 0,45 & $-5,7$ & 35,2 & 792,7 & 0 \\
\hline ŞANLIURFA & 14,92 & 87,04 & 0,35 & 2,2 & 38,7 & 458,4 & 1 \\
\hline UŞAK & 0,71 & 59,30 & 0,65 & $-1,2$ & 30,6 & 544,5 & 1 \\
\hline VAN & 32,96 & 85,17 & 0,37 & $-7,7$ & 28,2 & 387,4 & 1 \\
\hline YOZGAT & 27,11 & 44,98 & 0,49 & $-5,2$ & 26,5 & 578,7 & 1 \\
\hline ZONGULDAK & 3,08 & 88,36 & 0,55 & 3,4 & 25,3 & 1216,8 & 0 \\
\hline AKSARAY & 34,99 & 49,29 & 0,51 & $-3,6$ & 30,5 & 345,7 & 1 \\
\hline BAYBURT & 21,89 & $-7,92$ & 0,54 & $-10,8$ & 27,4 & 438,3 & 0 \\
\hline KARAMAN & 8,10 & 73,68 & 0,59 & $-3,8$ & 31,1 & 329,4 & 1 \\
\hline KIRIKKALE & 41,38 & 77,35 & 0,63 & $-2,9$ & 31 & 382,6 & 0 \\
\hline BATMAN & 0,94 & 90,82 & 0,32 & $-1,5$ & 39,4 & 488,8 & 0 \\
\hline ŞIRNAK & 4,89 & 92,90 & 0,32 & $-1,1$ & 33,3 & 683,7 & 0 \\
\hline BARTIN & 0,00 & 73,83 & 0,56 & 0,3 & 28,2 & 1040,5 & 0 \\
\hline ARDAHAN & 28,45 & $-208,96$ & 0,35 & -17 & 24,4 & 554,1 & 1 \\
\hline IĞDIR & 6,37 & 45,53 & 0,36 & $-8,1$ & 33,2 & 256 & 0 \\
\hline YALOVA & 37,88 & 95,33 & 0,62 & 3,3 & 28,7 & 748,7 & 0 \\
\hline KARABÜK & 43,05 & 81,73 & 0,63 & $-0,5$ & 32,5 & 489,8 & 0 \\
\hline KiLis & 9,50 & 94,28 & 0,40 & 2,2 & 36,2 & 494,6 & 0 \\
\hline OSMANIYE & 0,85 & 87,34 & 0,41 & 3,4 & 34,2 & 834,8 & 0 \\
\hline DÜZCE & 0,00 & 85,41 & 0,53 & 0,4 & 29 & 822,1 & 0 \\
\hline
\end{tabular}

In the fourth stage of study, when selection problem of facility place for beef farming is solved with the help of Visual Promethee package program, it was seen that Yalova is the first, Kars was the last. The results are shown in Table 4.

Table 4: Sequencing Results Calculated by PROMETHEE

\begin{tabular}{|l|c|c|c|}
\hline \multicolumn{1}{|c|}{ Provinces } & Phi & Phi+ & Phi- \\
\hline YALOVA & 0,6341 & 0,7604 & 0,1263 \\
\hline BURSA & 0,4783 & 0,6800 & 0,2018 \\
\hline MERSIN & 0,4560 & 0,6696 & 0,2136 \\
\hline ANKARA & 0,4420 & 0,6623 & 0,2203 \\
\hline GIRESUN & 0,4355 & 0,6590 & 0,2235 \\
\hline
\end{tabular}




\begin{tabular}{|c|c|c|c|}
\hline ORDU & 0,4350 & 0,6591 & 0,2241 \\
\hline KOCAELI & 0,4069 & 0,6464 & 0,2395 \\
\hline ANTALYA & 0,4061 & 0,6464 & 0,2403 \\
\hline SIIRT & 0,3168 & 0,6023 & 0,2855 \\
\hline KiLIS & 0,2764 & 0,5819 & 0,3055 \\
\hline KARABÜK & 0,2701 & 0,5776 & 0,3075 \\
\hline VAN & 0,2636 & 0,5736 & 0,3100 \\
\hline HATAY & 0,2528 & 0,5680 & 0,3153 \\
\hline ŞANLIURFA & 0,2499 & 0,5664 & 0,3165 \\
\hline ISTANBUL & 0,2483 & 0,5676 & 0,3194 \\
\hline MALATYA & 0,2324 & 0,5576 & 0,3253 \\
\hline KAHRAMANMARAŞ & 0,2199 & 0,5510 & 0,3311 \\
\hline ESKIŞEHIR & 0,2151 & 0,5509 & 0,3358 \\
\hline ARTVIN & 0,1756 & 0,5304 & 0,3548 \\
\hline KIRIKKALE & 0,1744 & 0,5294 & 0,3550 \\
\hline MARDIN & 0,1689 & 0,5263 & 0,3574 \\
\hline ZONGULDAK & 0,1656 & 0,5261 & 0,3605 \\
\hline RizE & 0,1649 & 0,5201 & 0,3553 \\
\hline MANISA & 0,1530 & 0,5178 & 0,3648 \\
\hline ŞIRNAK & 0,1359 & 0,5116 & 0,3758 \\
\hline ADANA & 0,1136 & 0,5005 & 0,3869 \\
\hline BILECIK & 0,1121 & 0,4986 & 0,3865 \\
\hline IZMiR & 0,1011 & 0,4939 & 0,3928 \\
\hline KAYSERI & 0,0796 & 0,4831 & 0,4035 \\
\hline SAMSUN & 0,0760 & 0,4793 & 0,4033 \\
\hline MUĞLA & 0,0750 & 0,4810 & 0,4060 \\
\hline TUNCELI & 0,0720 & 0,4799 & 0,4079 \\
\hline OSMANIYE & 0,0685 & 0,4781 & 0,4096 \\
\hline GAZIANTEP & 0,0546 & 0,4710 & 0,4164 \\
\hline NEVŞEHIR & 0,0445 & 0,4635 & 0,4190 \\
\hline TRABZON & 0,0347 & 0,4538 & 0,4190 \\
\hline HAKKARI & 0,0160 & 0,4519 & 0,4359 \\
\hline BATMAN & 0,0069 & 0,4471 & 0,4403 \\
\hline ISPARTA & 0,0063 & 0,4448 & 0,4385 \\
\hline SINOP & $-0,0014$ & 0,4419 & 0,4433 \\
\hline KONYA & $-0,0025$ & 0,4400 & 0,4425 \\
\hline DENIZLi & $-0,0128$ & 0,4345 & 0,4473 \\
\hline BiTLis & $-0,0136$ & 0,4369 & 0,4505 \\
\hline ELAZIĞ & $-0,0145$ & 0,4344 & 0,4489 \\
\hline KÜTAHYA & $-0,0199$ & 0,4315 & 0,4514 \\
\hline SivAS & $-0,0335$ & 0,4245 & 0,4580 \\
\hline ÇORUM & $-0,0366$ & 0,4235 & 0,4601 \\
\hline ADIYAMAN & $-0,0479$ & 0,4194 & 0,4673 \\
\hline SAKARYA & $-0,0651$ & 0,4111 & 0,4763 \\
\hline DÜZCE & $-0,0688$ & 0,4039 & 0,4726 \\
\hline TEKIRDAĞ & $-0,0724$ & 0,4071 & 0,4795 \\
\hline DIYARBAKIR & $-0,0726$ & 0,4051 & 0,4778 \\
\hline ÇANAKKALE & $-0,0768$ & 0,4025 & 0,4793 \\
\hline
\end{tabular}




\begin{tabular}{|l|l|l|l|}
\hline AYDIN & $-0,0986$ & 0,3921 & 0,4908 \\
\hline KARAMAN & $-0,1173$ & 0,3823 & 0,4995 \\
\hline ERZINCAN & $-0,1210$ & 0,3808 & 0,5018 \\
\hline AKSARAY & $-0,1520$ & 0,3656 & 0,5176 \\
\hline AFYONKARAHISAR & $-0,1535$ & 0,3638 & 0,5173 \\
\hline TOKAT & $-0,1573$ & 0,3600 & 0,5173 \\
\hline ÇANKIRI & $-0,1785$ & 0,3520 & 0,5305 \\
\hline BALIKESiR & $-0,1970$ & 0,3420 & 0,5390 \\
\hline NiĞDE & $-0,1990$ & 0,3436 & 0,5426 \\
\hline YOZGAT & $-0,2009$ & 0,3414 & 0,5423 \\
\hline BINGÖL & $-0,2126$ & 0,3374 & 0,5500 \\
\hline AMASYA & $-0,2253$ & 0,3283 & 0,5535 \\
\hline AĞRI & $-0,2289$ & 0,3274 & 0,5563 \\
\hline KIRŞEHIR & $-0,2431$ & 0,3214 & 0,5645 \\
\hline KASTAMONU & $-0,2480$ & 0,3173 & 0,5653 \\
\hline GÜMÜŞHANE & $-0,2610$ & 0,3126 & 0,5736 \\
\hline BARTIN & $-0,2641$ & 0,3064 & 0,5705 \\
\hline BOLU & $-0,2673$ & 0,3103 & 0,5775 \\
\hline UŞAK & $-0,2851$ & 0,2963 & 0,5814 \\
\hline ERZURUM & $-0,3076$ & 0,2873 & 0,5949 \\
\hline ARDAHAN & $-0,3371$ & 0,2729 & 0,6100 \\
\hline MUŞ & $-0,3519$ & 0,2659 & 0,6178 \\
\hline EDIRNE & $-0,3864$ & 0,2501 & 0,6365 \\
\hline KIRKLARELI & $-0,4244$ & 0,2311 & 0,6555 \\
\hline BURDUR & $-0,4365$ & 0,2230 & 0,6595 \\
\hline BAYBURT & $-0,4620$ & 0,2125 & 0,6745 \\
\hline IĞDIR & $-0,5860$ & 0,1509 & 0,7369 \\
\hline KARS & $-0,6233$ & 0,1300 & 0,7533 \\
\hline
\end{tabular}

\section{CONCLUSION}

Manufacturers in the livestock sector live problems such as inefficiency, inadequate use of technology, unconsciousness in union or cooperative style organization, and disconnection from the market as it is in many other sectors.

The productivity and profit increase which are main objectives of the animal husbandry will increase depending on the correct selection of the facility place of the enterprises. According to traditional methods, there are many problems in control and reduction of costs due to high investment, operating costs and labor demands in agricultural holdings in cattle feeding which are carried out in closed system stalls (Toker et al., 2010).

In this study, AHP and Promethee methods of multi criteria decision making methods were used for choosing beef farming place. For selection; seven criteria were defined as feed plant area percentages, percentage of demand of meat, city development index, average minimum temperature, average maximum temperature, annual rainfall quantity, grant supports. It is aimed that to select the correct criteria for the beef farming place, to find the weights of these selected criteria, and to determine the preference functions of the found weights were performed with Visual Promethee program.

As a result of the evaluations, it was determined that preference of Yalova province is suitable for the selection of the place. The province of Kars should be the last one to be preferred.

When the top ten provinces in the list are evaluated, it is seen that they are the ones in Marmara, Mediterranean, Black Sea, Central Anatolia and Southeastern Anatolia regions in Turkey. These five regions are emerging as priority regions for the establishment of a new district. 


\section{REFERENCES}

Athawale, V.M. ve Chakraborty, S. 2010. "Facility Location Selection Using PROMETHEE II Method", Proceedings of the 2010 International Conference on Industrial Engineering and Operations Management Dhaka, Bangladesh,pp: 59-63.

Bakan, H., 2013, “Analitik Hiyerarşi Yöntemiyle Üniversite Kurulması Uygun Olan İlçelerin Belirlenmesi” Ekonomi ve Yönetim Araştırmaları Dergisi, 2(2), s:43-63.

Çiftçioğlu, B., 2013, “İnşaat Sektöründe AHP Yöntemi ille Alt Yüklenici Seçimi: Bir Konut Projesinde Uygulama”, Yüksek Lisans Tezi, İstanbul Teknik Üniversitesi, İstanbul.

Çukur, F., Saner G., 2005, "Konvansiyonel ve Ekolojik Hayvancılık Sistemlerinin Sürdürülebilirliği ve Türkiye Üzerine Bir Değerlendirme”, Adnan Menderes Üniversitesi, Ziraat Fakültesi Dergisi, 2(1), s:39-44.

Dağdeviren, M. ve Eraslan, E. 2008, “PROMETHEE Sıralama Yöntemiyle Tedarikçi Seçimi”, Gazi Üniversitesi Mühendislik Mimarlık Fakültesi Dergisi, 23(1): 69-75.

Ekmekyapar, T., 1991, Hayvan Barınaklarında Çevre Koşullarının Düzenlenmesi, Atatürk Üniversitesi Ziraat Fakültesi Yayınları, Erzurum.

Genç, T., Masca, M. 2013, “Topsis ve Promethee Yöntemleri ile Elde Edilen Üstünlük Sıralamalarının Bir Uygulama Üzerinden Karşılaştırılması", Afyon Kocatepe Üniversitesi iiBF Dergisi, 15(2): 539-566.

Hacıbebekoğlu, A., Hacıbebekoğlu M., Çetinel, S., Ülver, M. 2013, Büyükbaş Hayvan Besiciliği Yatırım Fizibilitesi, Karacadağ Kalkınma Ajansı Destek Programı.

http://arastirma.tarim.gov.tr/gaputaem/Belgeler/tar\%C4\%B1msal\%20veriler/gaputaem\%20gncel/HAYVANCILIK\%20RAPORU\%202015.pdf

http://www.tepge.gov.tr/dosyalar/yayinlar/7b4e10c046074a319ca607fb3c7aae15.pdf

http://www.tkdk.gov.tr/Projelslemleri/Desteklenenlller

http://www.tuik.gov.tr/HbGetir.do?id=21871\&tb_id=3

https://www.mgm.gov.tr/veridegerlendirme/il-ve-ilceler-istatistik.aspx

Kokangül,A., Susuz, Z., 2009, "Integrated analytical hierarchy process and mathematical programming to supplier selection problem with quantity discount", Applied Mathematical Modelling, cilt: 33(3), pp. 1417-1429.

Kutay, N., Tektüfekçi, F., 2012, "Yönetsel Muhasebe Kararlarının Verilmesinde Bir Araç Olarak Promethee Sıralama Yöntemi ve Bir Uygulama", Verimlilik Dergisi, 3: 83-96.

Maragoudakı, R. ve Tsakiris, G., 2005, “Flood Mitigation Planning Using PROMETHEE”, European Water, 9(10): 51-58.

Ocaklı, B., Ertosun, Z., Demiröz, M., Horasan B., Peker, Ş., 2017, “Türkiye'de Hayvancılığın Durumu ve Et İthalatı", http://www.zmo.org.tr/resimler/ekler/cb16f6f3938e162_ek.pdf, accessing date: 15th April 2017

Ömürbek, N., Karaatlı, M, Eren, H., Şanlı,B., 2014, “AHP Temelli PROMETHEE Sıralama Yöntemi Ile Hafif Ticari Araç Seçimi”, Süleyman Demirel Üniversitesi İktisadi Ve İdari Bilimler Fakültesi Dergisi, cilt: 19, sayı: 4, pp. 47-64.

Ömürbek, N., Üstündağ, S., Helvacıoğlu, Ö., C., 2013, “Kurulus Yeri Seçiminde Analitik Hiyerarşi Süreci (AHP) Kullanımı: Isparta Bölgesi'nde Bir Uygulama", Yönetim Bilimleri dergisi, 11(21), s:101-116.

Özel, H. B., Karayılmazlar, S., Demirci, A., 2014, 'Bartın Havzasında Analitik Hiyerarşi Prosesi (AHP) Yöntemiyle Akdeniz Çam Türleri (Pinus brutia Ten. ve Pinus pinea L.) Kullanılarak Yapılacak Ağaçlandırma Çalışmaları İçin Yer Seçimi' , II. Ulusal Akdeniz Orman Ve Çevre Sempozyumu, Isparta.

Saaty, I.T., 1990, “How To Make A Decision: The Analytic Hierarchy Process”, European Journal of Operational Research, 48: 9-26.

Soba, M., 2012, “Promethee Yöntemi Kullanarak En Uygun Panelvan Otomobil Seçimi ve Bir Uygulama”, Journal of Yaşar University, 28(7): 4708-4721.

Şerefoğlu, Coşkun, 2008, SAPARD_IPARD programlarının Analiz Edilmesi-Besi İşletmelerinin IPARD Programındaki Yeri Üzerine Bir Araştırma, Atatürk Üniversitesi, Fen Bilimleri Enstitüsü Doktora Tezi, Erzurum.

Toker, M.T., Akdeniz, R. C., Ayhan, V., Boyar, S., Bayhan, A. K., Ünal, H. B., Yılmaz, H.İ., 2010, “Açık Besi Sığırcılığı İşletmelerinin Tasarımı”, Türkiye Ziraat Mühendisliği VII. Teknik Kongresi. TMMOB Ziraat Mühendisleri Odası (ZMO), Cilt:2, S.759-765, Ankara.

Ülke, K., 2016, AHP Yöntemiyle Çorum illinde AVM Kuruluş Yeri Seçimi, Hitit Üniversitesi Sosyal Bilimler Enstitüsü Yüksek Lisans Tezi, Çorum.

Vural, H., Fidan, H., 2007, "Türkiye'de Hayvansal Üretim ve Hayvancılık İşletmelerinin Özellikleri”, Tarım Ekonomisi Dergisi ; 13(2), s: 49 - 59 